BULLETIN Bulletin hispanique

HISPANIQUE Université Michel de Montaigne Bordeaux

117-1 | 2015

Les poètes des rhéteurs

\title{
Lope de Vega, La Malcasada
}

Éditions Orbis Tertius, Villeurbanne, 2014

\section{Heinz Peter Endress}

\section{CpenEdition}

Journals

Edición electrónica

URL: https://journals.openedition.org/bulletinhispanique/3935

DOI: 10.4000/bulletinhispanique.3935

ISSN: 1775-3821

Editor

Presses universitaires de Bordeaux

\section{Edición impresa}

Fecha de publicación: 1 junio 2015

Paginación: 381-383

ISBN: 979-10-300-0174-7

ISSN: 0007-4640

Referencia electrónica

Heinz Peter Endress, «Lope de Vega, La Malcasada», Bulletin hispanique [En línea], 117-1 | 2015,

Publicado el 01 septiembre 2015, consultado el 12 febrero 2022. URL: http://journals.openedition.org/

bulletinhispanique/3935 ; DOI: https://doi.org/10.4000/bulletinhispanique.3935

Este documento fue generado automáticamente el 12 febrero 2022.

Tous droits réservés 


\title{
Lope de Vega, La Malcasada
}

\author{
Éditions Orbis Tertius, Villeurbanne, 2014
}

\author{
Heinz Peter Endress
}

\section{REFERENCIA}

Lope de Vega, La Malcasada, Christian Andrés (ed.). Villeurbanne : Éditions Orbis Tertius, 2014, 292 p. ISBN 978-236783-033-9.

1 Se trata de un modelo de edición crítica. Una tesis doctoral y numerosos artículos dan fe de que el editor, Christian Andrés, es un buen conocedor de la obra de Lope de Vega. La Malcasada, comedia de enredo de 1621, se distingue por la madurez artística y por la lograda y convincente realización.

2 Situada en la corte madrileña, se desarrolla una divertida y animada acción con una original intriga amorosa. Feliciana, una madre autoritaria, domina a su hermosa hija Lucrecia y la fuerza a dos casamientos: primero con el viejo y rico don Julio, y después con Fabricio, el feo e impotente hijo de este. Dos pretendientes suplementarios, el jurista don Lisardo y el joven caballero don Juan rivalizan también por el favor de Lucrecia -antes de que en el final feliz sea el último quien la consiga-. Y, last but not least, hay que subrayar el rol del astuto y elocuente gracioso Hernando.

3 En el transcurso del texto hallamos una gran cantidad de notas que explican no sólo dificultades de lengua, elementos de la versificación y la presencia de figuras retóricas, sino también el contexto biográfico, literario e histórico, al igual que costumbres y vivencias del Siglo de Oro. La riqueza y variedad de estas informaciones denota la amplia erudición del especialista ${ }^{1}$ y contribuye de manera decisiva a la comprensión de la comedia.

4 Antes del texto de la propia comedia, cuidadosamente editado, hay una Introducción de 74 páginas, donde el lector puede hallar todo lo que le interesa. Consiste en nueve puntos más o menos extensos.

1. En unos preliminares se habla sucintamente de la Malcasada y se subraya el papel de Lope en la historia del teatro occidental. 
2. Se presentan las circunstancias de la vida y las obras de Lope en los años 1610-1615, que son las fechas de la probable composición de la Malcasada.

3. Se esboza el contexto bio-bibliográfico de «Lope y el teatro». Sobre todo se resume de manera muy acertada la mini-poética de Lope de El arte nuevo de hacer comedias en este tiempo y se enumeran sus características principales: los tres actos, el rechazo de las reglas aristotélicas, el gusto del público, el honor como el gran tema del teatro español, el papel del gracioso, la fusión de lo cómico y lo trágico y el sentimiento del amor. Además se habla de la materialidad de ese teatro, de los corrales, y de los elementos de una representación. A la propia comedia se le añade una loa, un baile, un entremés y una jácara.

4. Se hacen observaciones generales sobre la fórmula de la comedia nueva «que -como bien dice Andrés- consistía en presentar a los espectadores el reflejo animado de sus creencias y supersticiones, de su cultura y sus conocimientos, en suma, de su manera de pensar y sentir» (pp. 28-29). Globalmente se trata de una representación idealista de la realidad. Y especialmente a propósito de la Malcasada es preciso considerar la función convencional del gracioso como puente entre el público y el autor [o la pieza y el vulgo], de la simetría entre el comienzo y el fin y del recurso al italiano como lengua extranjera.

5. Se presenta de manera muy detallada el argumento de los tres actos de la divertida y salerosa comedia de la Malcasada. Habiendo resumido ya sucintamente el contenido arriba, me limitaré a indicar los motivos que determinan la acción de los personajes: amor, celos, casamientos, hermosura o fealdad, la virtud y la buena fama, autoritarismo o libertad, herencia y dinero, riqueza o pobreza, burlas y disfraces.

6. Se hacen observaciones sobre el poliglotismo en la Malcasada, sobre el uso satírico y burlesco del italiano y del latín (jurídico y macarrónico). El italiano se asocia principalmente a la ridiculización de Fabricio, el segundo marido, pero al mismo tiempo Lope de Vega muestra su propio conocimiento de esta lengua y de sus dialectos. Y con ello se confiere más verosimilitud al personaje de Fabricio. Nuestro autor lo ilustra mediante ejemplos. En cuanto al latín, lo oímos sobre todo pronunciado por boca de Lisardo, el letrado pedante que cita leyes, y de Hernando que «domina» el latín macarrónico. En los dos casos, tanto con respecto al italiano como al latín, su uso sirve predominantemente a la dimensión cómica.

7. Bajo «fenómenos intertextuales» se presentan y se analizan con acierto una serie de textos literarios que pudieron influir en la Malcasada, pero que por razones de concentración no cito aquí.

8. «Lenguaje, poesía, didascalias» es el título del penúltimo apartado. Mediante un preciso y detallado análisis de la primera escena de la Malcasada, nuestro autor estudia aquí la función emotiva o expresiva y a continuación la función poética de la pieza. Está claro que «el propio dramaturgo tenía plena conciencia de las potencialidades dramáticas del lenguaje.» En cuanto a las didascalias o acotaciones escénicas constata que constituyen un metatexto o texto dramático secundario y que escasean en la Malcasada. Las didascalias explícitas, expressis verbis indicadas, no son problemáticas, las ímplícitas en cambio que se distribuyen por el texto son mucho más interesantes.

9. Era indispensable la evocación de Madrid como color local en la Malcasada. Para el especialista -y no sólo para él- «se respira un aire de corte madrileña.» Es un mundo motivado por el dinero y el amor, caracterizado por la vida animada. Lugares típicos como la Iglesia del Carmen y el Soto se mencionan más de una vez. 
5 Hasta aquí los puntos numerados de la Introducción. Siguen todavía un cuadro con la versificación, los criterios de la edición y una exhaustiva bibliografía.

6 Con esto concluye la clara, precisa y completa edición de Christian Andrés. No falta nada. El curioso lector de la Malcasada acaba perfectamente informado.

\section{NOTAS}

1. A veces se pasa un poco de la raya, por ejemplo con el galanteo en las iglesias (p. 97) o a propósito del apellido gallego de Ribadaneyra (pp. 138 -139).

\section{AUTORES}

\section{HEINZ PETER ENDRESS}

Université de Freiburg 